\title{
Synthesis photophysical studies of some furfurylnitrones: highly selective chemosensors for Zn2+ and DFT studies
}

\author{
EzhumalaiDhineshkumar $^{1}$, MathivananIyappan ${ }^{1}$, RajendranGanapathi $^{1}$, ChinnaduraiAnbuselvan $^{1}$ *\# \\ ${ }^{1}$ Department of Chemistry, Annamalai University, Annamalainagar - 608 002, India \\ *Corresponding author E-mail:cas_amu@yahoo.co.in \\ \# Presently at PG and Research department of Chemistry, Government Arts college, Chidambaram-608102, India
}

\begin{abstract}
New aldonitrones(1-4) were synthesized and characterized by UV-vis, fluorescence, FT-IR, ${ }^{1} \mathrm{H}$ and ${ }^{13} \mathrm{C}$ NMR spectral analyses. The absorption and fluorescence sensing spectra of the compounds were precise in different polarity of solvent. The solvent polarity parameters have been used to propose a quantitative approach towards the reliable stability of the electronic ground and excited state species. Photochemical behaviors of the compounds were analyzed by applying multi-linear correlation methods. The characterized compounds 1-4 show a chemosensing detection of zinc ion in aqueous solution. Besides, the fluorescence spectroscopic responses were reversible when the $\mathrm{Zn}^{2+}$ chelating reagentEDTANa2. The phenomenon proves that these compounds to show a sensitivity "onoff" sensor for $\mathrm{Zn}^{2+}$. Further, to recognize the molecular structure, electronic and optical properties and DFT calculations of the molecules were formed.
\end{abstract}

Keywords: Aldonitrones; Solvaotochromic Absorption; Zn2+ Sensor; DFT.

\section{Introduction}

A fluoresce chemosensors is a assign of physicochemical properties change on interaction with an active species. The pledge of fluorescent detection is superior to other analytical measurements is very high promise, sensitivity, simplicity of use, and low expenditure (Butler et al. 2008; Yanagida et al. 2009; Szmacinski et al. 1993; Lakowicz et al. 1983; Czarnik et al. 1994; Lakowicz et al. 1995).

Zinc ion $\left(\mathrm{Zn}^{2+}\right)$ is the key note of awareness ascribing to the biological significance. Zinc ion is a readily broad range of application used transition metal ion amongst $(2.3 \mathrm{~g} \mathrm{Zn}$ for an normal person) (Dudev et al. 2003). $\mathrm{Zn}^{2+}$ is now recognized as one of the most important cations in catalytic centres and structural cofactors of many $\mathrm{Zn}^{2+}$-containing enzymes and DNA-binding proteins (e.g., transcriptions factors) and play a vital constituent of various protein scaffolds (e.g., carbonicanhydrase and zinc finger protein) (Laity et al. 2001). Zinc ionhas been well-known to perform as a practical component of proteins catalytic site of enzymes (Datta et al. 2013) and plays verycrucial roles in gene transcription andenzymatic function(Vallee et al. 1993). The occurrence of neurobiology of $\mathrm{Zn}$ (II) has become a subject of raising awareness (Scrimgeouret al. 2007; Bush et al. 2000; Frederickson et al. 2004) and a key note of element implicated in a plethora of biological aspects, like as cellular metabolism, neurotransmission, and apoptosis and is also drawn in the pathological consequences manifested in several diseases such as Alzheimer's disease, epilepsy, ischemic stroke, infantile diarrhoea, gene transcription, immune function, mammalian reproduction brain function and pathology, (Frederickson et al. 2005; Bush et al. 1994; Silva et al. 1997). $\mathrm{Zn}^{2+}$ is vital for wound healing and during the increase the growth of adolesence human body, babyhood and pregnancy. Even though $\mathrm{Zn}^{2+}$ is strongly jumped to enzymatic condition and proteins, free zinc pools survive in a quantity of tissues, the brain, intestine, pancreas, and retina. Because $\mathrm{Zn}^{2+}$ is a spectroscopically silent feature due to its $\mathrm{d}^{10}$ electronic configuration, sensing for the finding of $\mathrm{Zn}^{2+}$ have been established intensively. Several literature reviews have been focused on various notes of zinc fluorescent chemosensors (Carol et al. 2007; Kimura et al. 2001; Que et al. 2008). An enhancement of fluorescent chemosensor for the finding of these metal cations is the great awareness in environmental ones and biological chemistry.

Nitrones (Hamer etal.1964) means (nitrogen-ketone) which involves $\mathrm{C}=\mathrm{N}$ group are established into two type's aldo and ketonitrones with alkyl, aryl substituents on $\mathrm{C} \alpha$ instead of hydrogen atoms. Nitrones which are extensively studied for the characterization of stereoselective 1,3-dipolar cycloaddition. (Tufariello et al. 1979; Black et al. 1975; Huisgenetal1963. Hassan et al. 2000). It's employed to the oxidant of toxic mercuric oxide; in order to establish the aspects of nitrones due to its mild reaction condition has been widely illustrated. In a single step process, owing to its 1, 3dipolar cyclodeviation is a salient feature of stereometer has been summarized (Turfariello et al.1984; Turfariello et al. 1979).

From the above account studies of nitrones, to intend the arrangement of aldosterones and their distinguish module of fluorescence sensor is an essential goal for organic and analytical chemists. Therefore, research on chemosensing nature of metal-ion-selective fluorescent sensing have been great attention from chemicalscientists, and immense achievements have been reported (Kikuchi et al. 2010; Xu et al. 2010; Quang et al. 2010; Wu et al. 2011), we comprehensive the synthesis, characterization, and discriminating recognition behaviour of aldosterones derivatives as an extremely well-organized chemosensors for $\mathrm{Zn}^{2+}$.Emission spectroscopy is extensively used high selectivity, simple application, and low cost. In the present work, substituted, aldosterones were de- 
tailed explanation of UV-Vis, FT-IR, ${ }^{1} \mathrm{H}$ and ${ }^{13} \mathrm{C}$ NMR techniques, emission spectroscopy. To design the sensor shows tremendously high selectivity compared to the recently determined $\mathrm{Zn}^{2+}$ sensors ascribed to the very high association constants for the binding of $\mathrm{Zn}^{2+}$. Since aldosterones are non toxic and studies are made in an aqueous ethanol mediums those be able to mark $\mathrm{Zn}^{2+}$ in the biological system.

\subsection{Synthesis of aldonitrones (1-4)}

On the event of the stirred mixture of ammonium chloride (1.55 $\mathrm{g})$, freshly distilled nitrobenzene $(3.1 \mathrm{~g})$ and zinc dust $(3.75 \mathrm{~g})$ was adequate amounts over a period of $30 \mathrm{~min}$. After completion of the reaction, the filtrate is saturated with sodium chloride and cooled in ice. $\beta$-Phenylhydroxylamine, which separated out as yellow crystals, was collected and dried.A mixture of equimolar amounts of 2-nitro furfuraldehyde and $\beta$-phenylhydroxylamine in minimum amounts of the ethanol was heated in a water bath with occasional shaking for $1 \mathrm{~h}$. The solution was diluted with water until it became solid mass. The solution mixture was kept at room temperature for about $3 \mathrm{hrs}$. The nitrones (1-4) that separated was recrystallized in the ratio of benzene-petroleum.

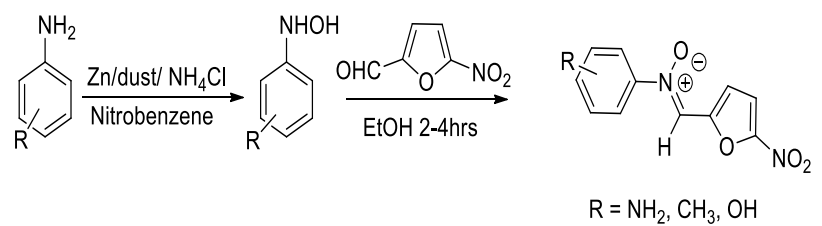

Scheme 1: Synthetic Pathway of Aldonitrones.

\section{Results and discussion}

The bands in the interval $3042-3030 \mathrm{~cm}^{-1}$ are attributed to be aromatic $v_{\mathrm{C}-\mathrm{H}}$. A stretching frequency at $2920-2860 \mathrm{~cm}^{-1}$ indicated is that aliphatic $v_{\mathrm{C}-\mathrm{H}}$. The band at $1545-1500 \mathrm{~cm}^{-1}$ recognized to $v_{\mathrm{C}=\mathrm{N}}$. A strong intense band at $1485-1460 \mathrm{~cm}^{-1}$ indicate that
$v_{\mathrm{C}=\mathrm{C}}$ of the benzene nucleus. The frequency was observed at $1084-1013 \mathrm{~cm}^{-1}$ attributed to $v_{\mathrm{N}-\mathrm{O}}$ substituted furan ring frequency exhibit at $1180-1154 \mathrm{~cm}^{-1}$. As seen from ${ }^{1} \mathrm{H}$ NMR spectral data, the aromatic signal appeared throughout the region 7.29-8.05 ppm. The $\mathrm{C}-\mathrm{H}$ protons in the title compounds are appeared around $8.40 \mathrm{ppm}$. In compound 2 , the $\mathrm{NH}_{2}$ proton observed at 6.12 $\mathrm{ppm}$. In compound 3 , the $\mathrm{OH}$ protonattributed at $5.56 \mathrm{ppm}$. The methyl proton appeared as a singlet at $2.42 \mathrm{ppm}$ in compound 4. The $\mathrm{C}-\mathrm{H}$ carbons in the molecular compounds are around $174.11 \mathrm{ppm}$. In all the cases the aromatic carbons described at $112.7-149.11 \mathrm{ppm}$. The methyl carbon described at $29.73 \mathrm{ppm}$ for compound 3 . The observed spectral signals corroborate formation of compounds 1-4.

\subsection{Absorption and fluorescence spectroscopy}

The electronic absorption spectra of the compounds under study in various solvents of diverse polarity are reported in Table 1. The data reveal that the compounds absorb around $390 \mathrm{~nm}$. The absorption is independent of solvent polarity. Which involve due to $n-\pi^{*}$ transition of whole electronic systems of the title compounds with a considerable charge transfer (CT) character originating mainly from benzenoid moiety and pointing towards the hetero furfuraldehyde ring which is characterized by the high electron acceptor.The charge transfer nature of this group to detect a deduced from its broadness in $\lambda_{\max }$. This band acquire substantial shift toward lower energy when ' $R$ ' is an electron donor compared with its position in the case of ' $R$ '" being an electron acceptor. This shift can be consideredas a good proof for the charge transfer character. Uv-visible spectroscopy of 1-4 are shown in Fig. 1. A weak second band in almost all the compounds detailed in the wavelength range $305 \mathrm{~nm}$ which is ascribed to $\pi-\pi *$ electronic transition. The fluorescence spectra are determined by exciting the sample at its longest absorption maximum. The values are given is Table 1 . The sensing behaviors of the title compound have a maximum around $430 \mathrm{~nm}$ which depends on solvent polarity.
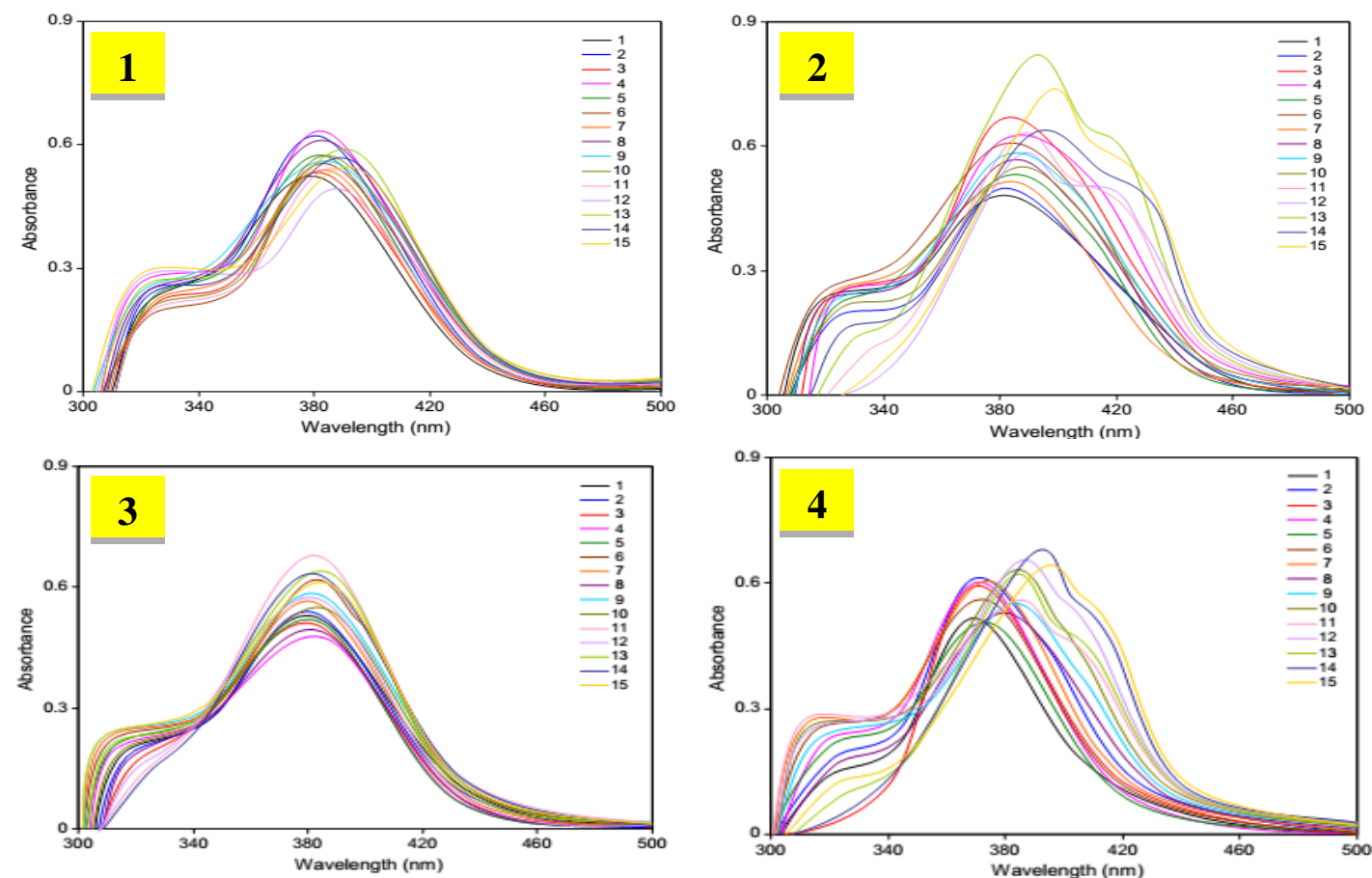

1. Hexane, 2. cyclohexane, 3. 1,4-dioxane, 4.benzene, 5. chloroform, 6. ethyl acetate, 7. t-butyl alcohol, 8. 1-butanol, 9. 2-propanal, 10.1-propanal, 11.ethanol, 12. methanol, 13. dimethylformamide, 14. acetonitrile and 15. dimethylsulfoxide.

Fig. 1: Absorption Spectra of Compounds 1-4 Recorded at Different Solvents. 

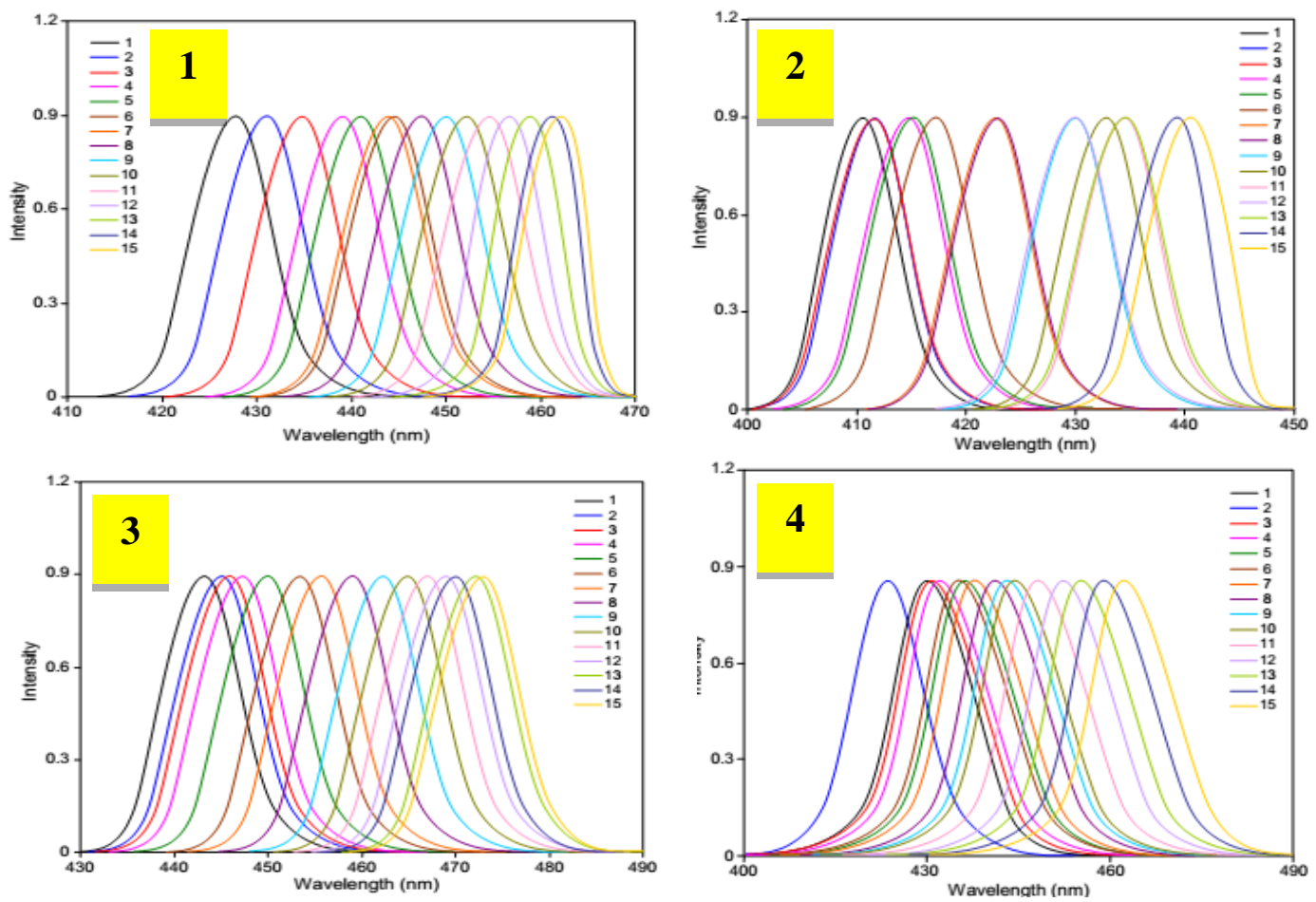

1.Hexane, 2. Cyclohexane, 3. 1,4-dioxane, 4. Benzene, 5. Chloroform, 6. Ethyl acetate, 7. t-butyl alcohol, 8. 1-butanol, 9.2-propanal, 10.1-propanal, 11.ethanol, 12. methanol, 13. dimethylformamide, 14. acetonitrile and 15. dimethylsulfoxide.

Fig.2: Fluorescence Spectra of Compounds 1-4 Recorded at Different Solvents.

Table 1: Absorption $\left(\Lambda_{\mathrm{ab}}\right)$, Fluorescence $\left(\Lambda_{\mathrm{ffu}}\right)$ Maximum andStokes Shifts of Compounds 1-4.

\begin{tabular}{|c|c|c|c|c|c|c|c|c|c|c|c|c|}
\hline Solvent & $\begin{array}{l}1 \\
\lambda_{\mathrm{ab}} \\
\mathrm{nm}\end{array}$ & $\begin{array}{l}\lambda_{\text {flu }} \\
\mathrm{nm}\end{array}$ & $\begin{array}{l}\text { Stokes shift } \\
\mathrm{cm}^{-1}\end{array}$ & $\begin{array}{l}2 \\
\lambda_{\mathrm{ab}} \\
\mathrm{nm}\end{array}$ & $\begin{array}{l}\lambda_{\text {flu }} \\
\mathrm{nm}\end{array}$ & $\begin{array}{l}\text { Stokes shift } \\
\mathrm{cm}^{-1}\end{array}$ & $\begin{array}{l}3 \\
\lambda_{\mathrm{ab}} \\
\mathrm{nm}\end{array}$ & $\begin{array}{l}\lambda_{\text {flu }} \\
\mathrm{nm}\end{array}$ & $\begin{array}{l}\text { Stokes shift } \\
\mathrm{cm}^{-1}\end{array}$ & $\begin{array}{l}4 \\
\lambda_{\mathrm{ab}} \\
\mathrm{nm}\end{array}$ & $\begin{array}{l}\lambda_{\text {flu }} \\
\mathrm{nm}\end{array}$ & $\begin{array}{l}\text { Stokes shift } \\
\mathrm{cm}^{-1}\end{array}$ \\
\hline Hexane & 370 & 411 & 2696 & 379 & 428 & 3021 & 380 & 430 & 3060 & 380 & 443 & 3742 \\
\hline 1,4-Dioxane & 371 & 412 & 2682 & 381 & 434 & 3205 & 383 & 431 & 2908 & 381 & 446 & 3825 \\
\hline Benzene & 372 & 414 & 2727 & 382 & 439 & 3399 & 386 & 433 & 2812 & 382 & 448 & 3857 \\
\hline Chloroform & 374 & 415 & 2772 & 382 & 441 & 3502 & 385 & 436 & 3038 & 382 & 450 & 3956 \\
\hline Ethyl acetate & 373 & 417 & 2829 & 383 & 444 & 3587 & 382 & 435 & 3190 & 383 & 453 & 4035 \\
\hline t-Butyl alcohol & 375 & 423 & 2944 & 383 & 443 & 3536 & 384 & 437 & 3158 & 380 & 456 & 4386 \\
\hline 1-Butanol & 380 & 423 & 2875 & 384 & 448 & 3720 & 383 & 440 & 3382 & 381 & 459 & 4460 \\
\hline 2-Propanol & 383 & 430 & 2904 & 385 & 450 & 3752 & 385 & 442 & 3350 & 382 & 462 & 4533 \\
\hline 1-Propanol & 384 & 433 & 2947 & 387 & 452 & 3716 & 387 & 444 & 3317 & 383 & 465 & 4604 \\
\hline Ethanol & 386 & 435 & 2918 & 388 & 454 & 3747 & 389 & 447 & 3336 & 382 & 467 & 4765 \\
\hline Methanol & 387 & 430 & 2885 & 390 & 457 & 3759 & 390 & 452 & 3517 & 380 & 469 & 4994 \\
\hline Dimethylformamide & 384 & 435 & 3053 & 392 & 459 & 3724 & 394 & 456 & 3451 & 385 & 472 & 4788 \\
\hline Acetonitrile & 393 & 439 & 2908 & 391 & 461 & 3883 & 397 & 459 & 3402 & 381 & 470 & 4970 \\
\hline Dimethylsulfoxide & 395 & 441 & 2871 & 393 & 462 & 3811 & 399 & 462 & 3418 & 385 & 473 & 4811 \\
\hline
\end{tabular}

The charge transfer band place a shift of about $01-33 \mathrm{~nm}$ in the absorption spectra on changing the solvent from the ratio between ethanol to n-hexane of the fluorescence spectra show the larger shift as compared with the absorption spectra. The emission spectra of 1-4 are shown in Fig. 2. The less marked absorption shift with solvent denotes that the ground-stateenergy distribution is not affected to a major extent it happens due to the less polar nature of the dyes in the ground state rather than the excited level.

\subsection{Effect of solvents analysis of compounds 1-4}

The greatest magnitude of the Stokes shifts varies at different interval 2500 to $4000 \mathrm{~cm}-1$. The values of the Stokes shift are also used to detect of charge transfer transition. While changing the solvent from a low polar solvent like cylohexane to high polar like methanol shows a difference is Stokes shift about $700 \mathrm{~cm}-1$ again investigative of a charge transfer transition. One of the greatest magnitudes of the Stokes shift implies that the excited state geometry could be diverse from that of the ground state. The general examination is that there is an increase in the Stokes shift prin- ciples with increasing in polarity simultaneously, which shows an amplify in the dipole moment on excitation (Table 2).

When the Stokes shifts were plotted against the solvent polarity scale observed on the empirical limit ET(30), which considers also other interactions of specific quality in addition to the non-specific solvent effects. A fair linear correlation was observed in Fig. S 13. From the we can scrutinize clear evidence the specific solute/solvent interactions, and obligation that hydrogen bonding might give a significant crucial role for the stability of the title compounds by solvated with HBD solvents. Furthermore, as the show in a linear correlation analysis of emission energy covering wide range of ET(30) (14 kcal mol-1)with a single slope. This expansion has been explained as such due to the presence of unique excited state. At least two different sets of solvent scales can be found throughout the literature to exemplify these solvents properties. In the present analysis, the polarity, acidity and the basicity of the solvents are considered. Kamlet and Taft (Reichardt et al. 2006) put forward the $\pi^{*}, \alpha$ and $\beta$ respectively, to detailed perception of the respective properties of a given solvent (eqn. 1).

$\mathrm{y}=\mathrm{y}_{0}+\mathrm{a}_{\alpha} \alpha+\mathrm{b}_{\beta} \beta+\mathrm{c}_{\pi^{*}} \pi^{*}($ Kamlet-Taft $)$ 
The dominant coefficient affecting the absorption and emission band of compounds under investigation is that relating the polarity towards the solvent having a positive value, corroborating the solvatochromic shifts with the solvent polarity. For the compounds $1-4$, to better coefficient determining the electron releasing group of the solvent, $\beta$ has the large negative values, suggesting solvent basicity play a major role in Uv-visible and emission displacements, which can be due to the greatest aspects ofpositive charge on the oxygen atom to that the basic solvent stabilizes the structures' effect on basis solvatochromic shifts. The existence of good correlations between the Uv-visible and sensing charger of wavenumbers designed by multiple linear regression analysis the Taft considered solvent parameters and detect the correlation coefficients are given in Table 3 .

Table 2: Statistical Visualized of theKamlet-Taft Solvation Energy Relationship for the Absorption and Emission Spectral Data ofAldonitrones

\begin{tabular}{llllllll}
\hline Compound & Spectral data & Intercept $10^{5}$ & $\alpha\left(\mathrm{cm}^{-1}\right) 10^{5}$ & $\beta\left(\mathrm{cm}^{-1}\right) 10^{5}$ & $\pi^{*}\left(\mathrm{~cm}^{-1}\right) 10^{5}$ & $\mathrm{R}^{2}$ & $\begin{array}{l}\text { Number of } \\
\text { solvent }\end{array}$ \\
\hline \multirow{3}{*}{1} & Absorption $\left(v_{\mathrm{a}}\right)$ & 0.263 & -0.090 & 0.0125 & 0.0124 & 0.570 & 15 \\
& Fluorescence $\left(v_{\mathrm{f}}\right)$ & 0.231 & -0.028 & 0.0424 & 0.0291 & 0.590 & 15 \\
& Stokes shifts & 0.031 & 0.010 & 0.0049 & 0.0114 & 0.567 & 15 \\
& Absorption $\left(v_{\mathrm{a}}\right)$ & 0.263 & -0.029 & 0.0696 & -0.0538 & 0.522 & 15 \\
& Fluorescence $\left(v_{\mathrm{f}}\right)$ & 0.241 & -0.033 & 0.0736 & -0.0541 & 0.525 & 15 \\
3 & Stokes shifts & 0.028 & 0.023 & 0.0747 & 0.0574 & 0.645 & 15 \\
& Absorption $\left(v_{\mathrm{a}}\right)$ & 0.262 & -0.046 & 0.0117 & 0.0105 & 0.622 & 15 \\
& Fluorescence $\left(v_{\mathrm{f}}\right)$ & 0.223 & -0.027 & 0.0522 & 0.0376 & 0.479 & 15 \\
4 & Stokes shifts & 0.036 & -0.012 & 0.0880 & 0.0767 & 0.554 & 15 \\
& Absorption $\left(v_{\mathrm{a}}\right)$ & 0.263 & 0.019 & -0.0183 & 0.0043 & 0.690 & 15 \\
& Fluorescence $\left(v_{\mathrm{f}}\right)$ & 0.231 & -0.088 & 0.0971 & -0.0162 & 0.548 & 15 \\
\hline
\end{tabular}

Table 3: Statistical Treatment of the Kamlet-Taft Solvation Energy Relationship for the Absorption and Fluorescence Spectral Data of Aldonitrones in Aprotic and Protic Solvents

\begin{tabular}{|c|c|c|c|c|c|c|c|}
\hline Compound & Spectral data & Intercept $10^{5}$ & $\alpha\left(\mathrm{cm}^{-1}\right) 10^{5}$ & $\beta\left(\mathrm{cm}^{-1}\right) 10^{5}$ & $\pi^{*}\left(\mathrm{~cm}^{-1}\right) 10^{5}$ & $\mathrm{R}^{2}$ & Number of solvent \\
\hline \multicolumn{8}{|l|}{ Aprotic $^{\mathrm{a}}$} \\
\hline & Absorption $\left(v_{a}\right)$ & 0.254 & 0.184 & -0.013 & 0.224 & 0.996 & 15 \\
\hline \multirow[t]{3}{*}{1} & Fluorescence $\left(v_{\mathrm{f}}\right)$ & 0.217 & 0.297 & -0.022 & 0.378 & 0.992 & 15 \\
\hline & Stokes shifts & 0.375 & -0.079 & 0.753 & -0.1311 & 0.736 & 15 \\
\hline & Absorption $\left(v_{a}\right)$ & 0.256 & 0.358 & -0.285 & 0.476 & 0.872 & 15 \\
\hline \multirow[t]{3}{*}{2} & Fluorescence $\left(v_{\mathrm{f}}\right)$ & 0.228 & 0.373 & -0.288 & 0.478 & 0.976 & 15 \\
\hline & Stokes shifts & 0.032 & -0.083 & 0.373 & -0.048 & 0.849 & 15 \\
\hline & Absorption $\left(v_{a}\right)$ & 0.259 & 0.028 & -0.091 & 0.083 & 0.999 & 15 \\
\hline \multirow[t]{3}{*}{3} & Fluorescence $\left(v_{\mathrm{f}}\right)$ & 0.211 & 0.309 & -0.023 & 0.380 & 0.999 & 15 \\
\hline & Stokes shifts & 0.410 & -0.157 & 0.016 & -0.287 & 0.756 & 15 \\
\hline & Absorption $\left(v_{\mathrm{a}}\right)$ & 0.252 & 0.194 & -0.015 & 0.251 & 0.926 & 15 \\
\hline \multirow[t]{2}{*}{4} & Fluorescence $\left(v_{\mathrm{f}}\right)$ & 0.217 & 0.363 & -0.027 & 0.458 & 0.978 & 15 \\
\hline & Stokes shifts & 0.034 & -0.168 & 0.012 & -0.206 & 0.998 & 15 \\
\hline \multicolumn{8}{|l|}{ Protic $^{b}$} \\
\hline & Absorption $\left(v_{a}\right)$ & -0.92 & 9.10 & -8.01 & 5.14 & 0.979 & 15 \\
\hline \multirow[t]{3}{*}{1} & Fluorescence $\left(v_{\mathrm{f}}\right)$ & -1.94 & 1.23 & -2.31 & 1.44 & 0.950 & 15 \\
\hline & Stokes shifts & 1.51 & -8.19 & 1.51 & -9.21 & 0.936 & 15 \\
\hline & Absorption $\left(v_{\mathrm{a}}\right)$ & 0.92 & -3.26 & 5.32 & -2.89 & 0.836 & 15 \\
\hline \multirow[t]{3}{*}{2} & Fluorescence $\left(v_{\mathrm{f}}\right)$ & -1.62 & -8.76 & 1.60 & -9.68 & 0.869 & 15 \\
\hline & Stokes shifts & -1.53 & 8.44 & -1.54 & 9.39 & 0.924 & 15 \\
\hline & Absorption $\left(v_{a}\right)$ & 1.31 & -7.09 & 1.30 & -7.96 & 0.992 & 15 \\
\hline \multirow[t]{3}{*}{3} & Fluorescence $\left(v_{\mathrm{f}}\right)$ & 1.84 & -8.58 & 1.51 & -8.89 & 0.934 & 15 \\
\hline & Stokes shifts & 1.12 & -6.23 & 1.15 & -7.07 & 0.963 & 15 \\
\hline & Absorption $\left(v_{a}\right)$ & -3.53 & 2.16 & -4.07 & 2.54 & 0.926 & 15 \\
\hline \multirow[t]{2}{*}{4} & Fluorescence $\left(v_{f}\right)$ & -7.24 & 4.17 & -7.72 & 4.75 & 0.961 & 15 \\
\hline & Stokes shifts & 3.70 & -2.01 & 3.65 & -2.21 & 0.994 & 15 \\
\hline
\end{tabular}

a) Hexane, cyclohexane, 1,4-dioxane, benzene, ethyl acetate

b) 1-Butanol, 2-propanol, 1-propanol, ethanol, methanol.

\subsection{Evaluation of dipole moment}

Based on the quantum mechanical perturbation theory(Kawski et al. 2006) of the incorporation and fluorescence band shifts (in wavenumbers) in the solvents of different permittivity $(\varepsilon)$ and refractive index (n), the following equations are observed (Ghazy et al 2004).

$$
\begin{aligned}
& \bar{v}_{\mathrm{a}}-\bar{v}_{\mathrm{f}}=\mathrm{m}_{1} \mathrm{f}(\varepsilon, \mathrm{n})+\text { constant } \\
& \bar{v}_{\mathrm{a}}+\bar{v}_{\mathrm{f}}=\mathrm{m}_{2}[(\mathrm{f}(\varepsilon, \mathrm{n})+2 \mathrm{~g}(\mathrm{n})]+\text { constant }
\end{aligned}
$$

Where

$$
\mathrm{f}(\varepsilon, \mathrm{n})=\frac{2 \mathrm{n}^{2}+1}{\mathrm{n}^{2}+2}\left[\frac{\varepsilon-1}{\varepsilon+2}-\frac{\mathrm{n}^{2}-1}{\mathrm{n}^{2}+2}\right]
$$

Is solvent polarity parameter and

$$
\mathrm{G}(\mathrm{n})=\frac{3}{2}\left[\frac{\mathrm{n}^{4}-1}{\left(\mathrm{n}^{2}+2\right)^{2}}\right]
$$

With

$\mathrm{m}_{1}=\frac{2\left(\mu_{\mathrm{e}}-\mu_{\mathrm{g}}\right)^{2}}{\mathrm{hca}^{3}}$

$\mathrm{m}_{2}=\frac{2\left(\mu_{\mathrm{e}}^{2}-\mu_{\mathrm{g}}^{2}\right)}{\mathrm{hca}^{3}}$ 
Where $\mu_{\mathrm{g}}$ and $\mu_{\mathrm{e}}$ are the dipole moments of the ground and excited states respectively, ' $h$ ' is Planck's constant and 'c' is the velocity of light in vacuum. The parameters $\mathrm{m}_{1}$ and $\mathrm{m}_{2}$ are obtained from the description absorption and fluorescence band shifts $\left(\bar{v}_{\mathrm{a}}-\bar{v}_{\mathrm{f}}\right.$ and $\bar{v}_{\mathrm{a}}+\bar{v}_{\mathrm{f}}$ ) and solvent polarities from above equations. If the ground and excited states are parallel, the following expressions are obtained on the basis of relations (eqns. 6 and 7) (Kawski et al. 2002).

$$
\begin{aligned}
& \mu_{\mathrm{g}}=\frac{\mathrm{m}_{2}-\mathrm{m}_{1}}{2}\left[\frac{\mathrm{hca}^{3}}{2 \mathrm{~m}_{1}}\right]^{1 / 2} \\
& \mu_{\mathrm{e}}=\frac{\mathrm{m}_{1}+\mathrm{m}_{2}}{2}\left[\frac{\mathrm{hca}^{3}}{2 \mathrm{~m}_{1}}\right]^{1 / 2}
\end{aligned}
$$

And

$$
\mu_{\mathrm{e}}=\frac{\mathrm{m}_{1}+\mathrm{m}_{2}}{\mathrm{~m}_{2}-\mathrm{m}_{1}} \mu_{\mathrm{g}} ;\left(\mathrm{m}_{2}>\mathrm{m}_{1}\right)
$$

The Onsager radius ' $a$ ' of the solute molecule can be firm by using atomic increment method (Lippert et al. 1957; Lippert et al. 1955). Note that the solvent polarity function ' $\mathrm{f}(\varepsilon, \mathrm{n})$ ' is diverse from Lippert-Mataga function (Husain et al. 2012). Absorption maximum shows a general no dependence on polarity of the solvent and fluorescence maxima show modest dependences these observations propose that the ground state to establish the certain extent state. Thesensor also shows shift on varying the characteristic of the solvent. Therefore, the nature and execute the emission state may be different nature of these two class of solvents. These results are depicted in Table 4.

The scattered points in Figs.S14 and S15 forward interaction between solute and solvents the ratio of dipole moments are more than one. Table 5 presents a comparison of ground and excited state changes of the dipole moment of furfurylnitrones estimated experimentally described as using solvatochromic method. It is pivital to note that furfurylnitrones possess greater dipole moment in the excited state than in the ground state. The molecule exhibits a excited state which is more polar than the ground state for planar form.

Table 4: Evaluation of Dipole Moment

\begin{tabular}{|c|c|c|c|c|c|c|c|}
\hline Compound & Radius 'a' $(\AA)$ & $\mathrm{m}_{1}\left(\mathrm{~cm}^{-1}\right)$ & $\mathrm{m}_{2}\left(\mathrm{~cm}^{-1}\right)$ & $\mu_{\mathrm{g}}(\mathrm{D})$ & $\mu_{\mathrm{e}}(\mathrm{D})$ & $\Delta \mu=\mu_{\mathrm{e}}-\mu_{\mathrm{g}}(\mathrm{D})$ & $\mu_{\mathrm{e}} / \mu_{\mathrm{g}}$ \\
\hline 1 & 4.70037 & 3183 & 5099 & 1.73 & 7.49 & 5.76 & 4.32 \\
\hline 2 & 4.79414 & 2942 & 5031 & 1.87 & 7.14 & 5.27 & 3.81 \\
\hline 3 & 4.78266 & 3722 & 4973 & 1.25 & 8.73 & 7.48 & 6.98 \\
\hline
\end{tabular}

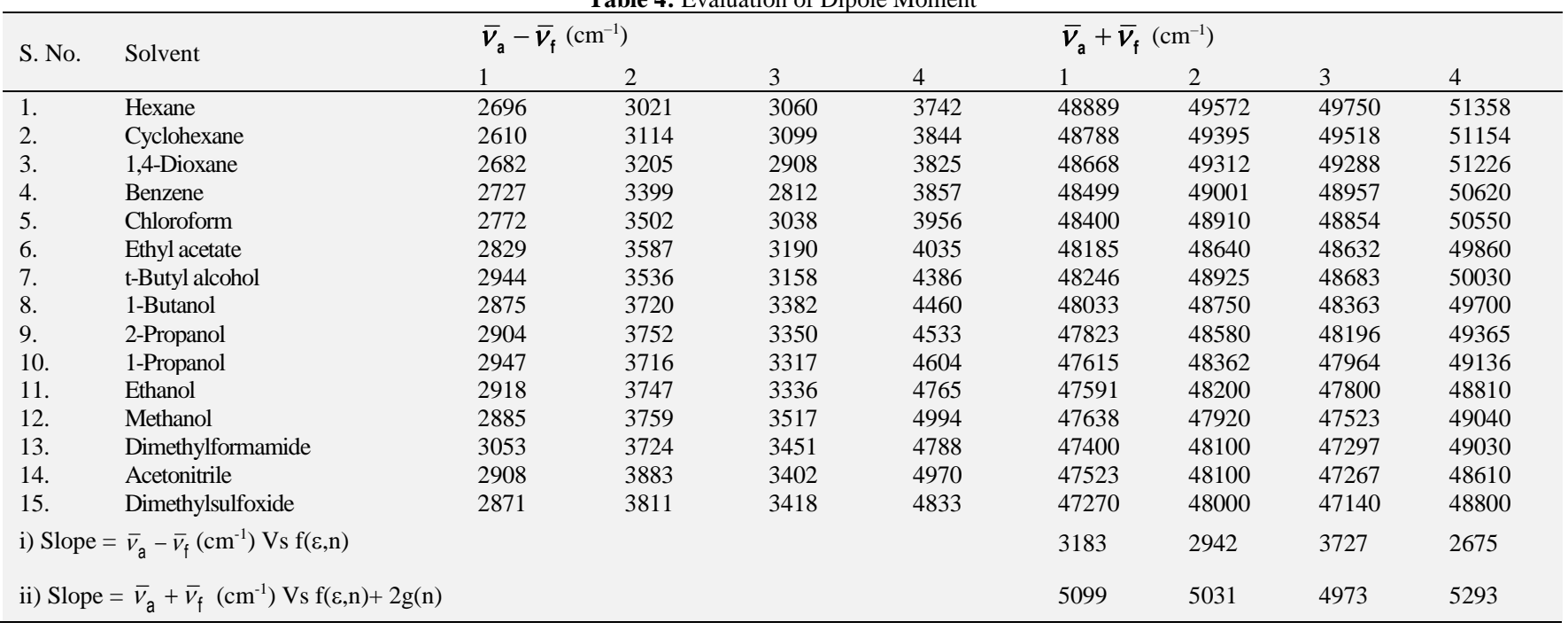

Table 5: Dipole Moments (In Debye*, D) of 1-4 in the Ground and Excited States Calculated by Kawski Correlation

${ }^{*} 1$ Debye $=3.33564 \times 10^{-30} \mathrm{~cm}=10^{-18}$ esu cm.a - Cavity radius. $\mathrm{m}_{1}$ and $\mathrm{m}_{2}-$ Slope obtained for Kawski correlation. $\mu_{\mathrm{g}}-$ Ground state dipole moment. $\mu_{\mathrm{e}}$ - Excited state dipole moment.

\subsection{Fluorometric response of $1-4$ to metal ions}

The recognition profiles of compounds $1-4$ were invested by measuring emission spectra against different metal ions $\left(\mathrm{Co}^{2+}, \mathrm{Cu}^{2+}, \mathrm{Cd}^{2+}\right.$ and $\mathrm{Ni}^{2+}$ ) is added. Fluorescence emission spectroscopy was used to monitor the competition event. The fluorescence quenching observed for $\mathrm{Zn}^{2+}(1-4)$. Besides, $\mathrm{Zn}^{2+}$ ions to all the four compounds in ethanol, and huge fluorescence quenching are ascribed at 450-460 $\mathrm{nm}$ (Fig. 6). The fluorescence sensing properties of quenching observed for $\mathrm{Zn}^{2+}$ is not seen for other metal ions, such as $\mathrm{Co}^{2+}, \mathrm{Cu}^{2+}$, $\mathrm{Cd}^{2+}$ and $\mathrm{Ni}^{2+}$ different metals were tested the small difference whenone equivalent was added. When more equivalents of $\mathrm{Co}^{2+}$, $\mathrm{Cu}^{2+}, \mathrm{Cd}^{2+}$ and $\mathrm{Ni}^{2+}$ were added, some reduction in the fluorescence was observed. This implies that these metal ions are displacing the
$\mathrm{Zn}^{2+}$ from compounds 1-4. To recognize the interface between compounds 1-4 and $\mathrm{Zn}^{2+}$, the fluorescence variation of compounds 1-4 was measured on addition of $\mathrm{Zn}^{2+}$ from 0 to $8 \mu \mathrm{M}$ (Fig. 7) .Their fluorescence spectra are the same when normalized. Furthermore, it is well recognized in coordination complex aspects of zinc with a ligand containing at least two nitrogen donor atoms is favored by the activation of the inert pair on the $\mathrm{Zn}^{2+}$ ion, leading to a shortening of the $\mathrm{Zn}-\mathrm{N}$ bond length and a much greater covalent bonding. To further examine thesensitivity for $\mathrm{Zn}^{2+}$ ions and competing over other metal ions, interferences to the selective response of receptor 1-4 to $\mathrm{Zn}^{2+}$ by coexisting ions were evaluated, no important interference in detection of $\mathrm{Zn}^{2+}$ was experimental in the presence of over other competitive cations. 

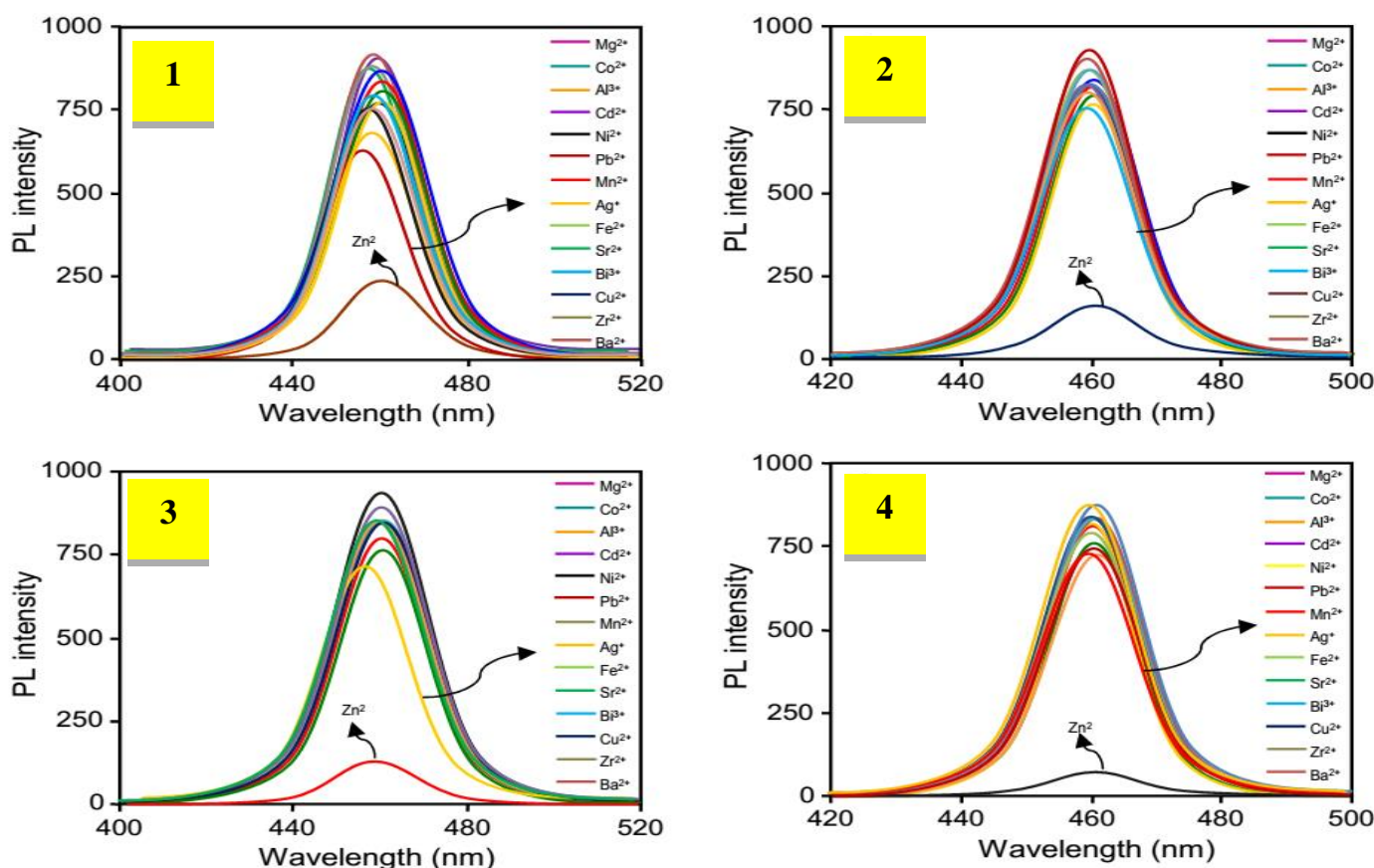

Fig. 6:Fluorescence Chemosensors Blocking by Metal Ion Binding of 1-4.
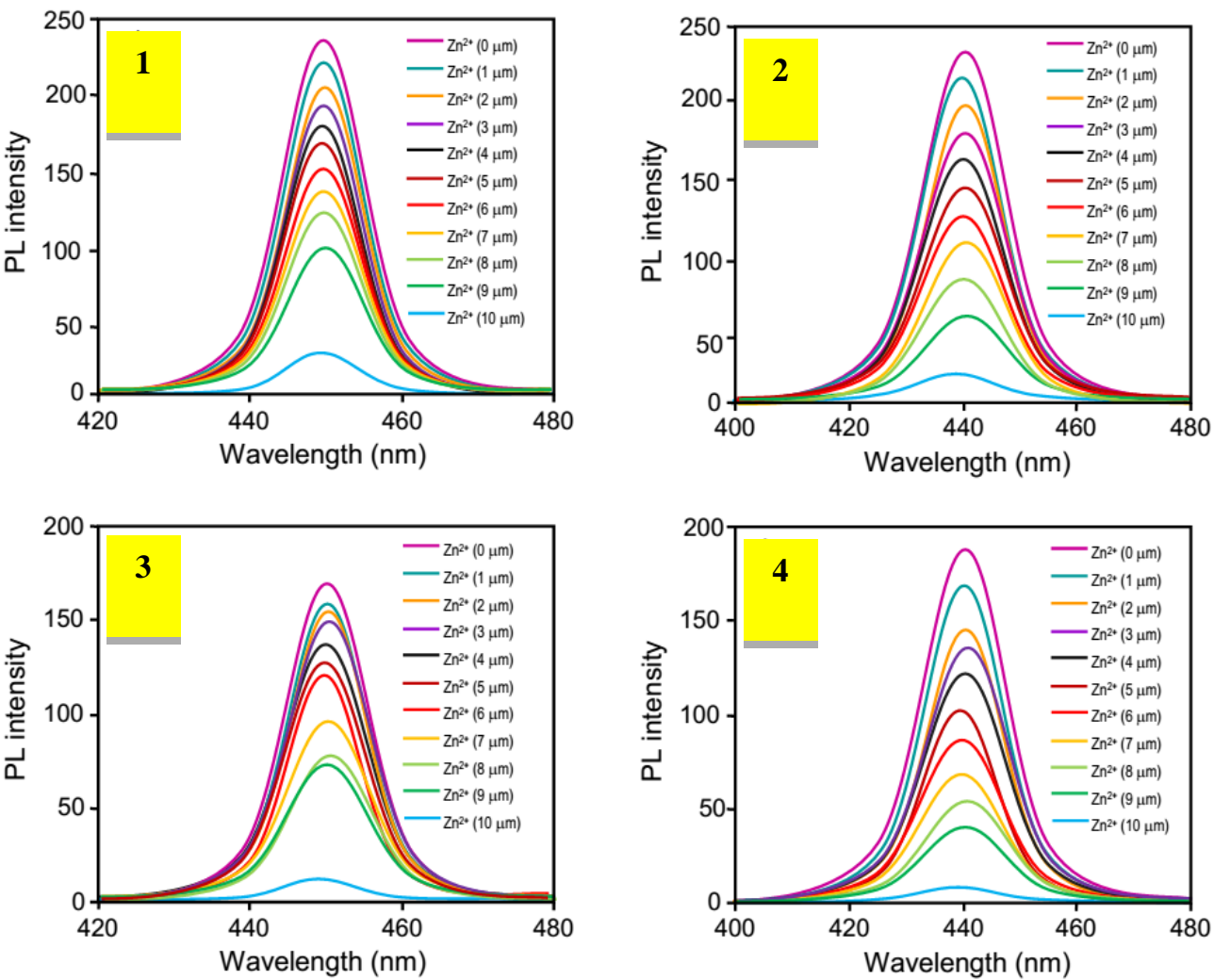

Fig. 7:Effect Of $\mathrm{Zn}^{2+}$ Ion Concentration on the Fluorescence Spectra of Compounds 1-4 Different Micrometer Concentration (0 to $\left.8 \mu \mathrm{M}\right)$ of $\mathrm{Zn}^{2+}$ Fluorescence Chemosensors Blocking Metal Ion Binding of 1-4.

Their fluorescence sensing, this established the same when normalized. As shown figures, there is a smooth transition from the free compound to the $\mathrm{Zn}^{2+}$ bound complex. A red shift of absorption peaks is often ascribed when $\mathrm{Zn}^{2+}$ binds to compounds. The absorption values tails off into the visible and thus would allow nitrones compounds to be excited in the noticeable light region.

\subsection{Effect of EDTANa2 on $\mathrm{Zn2}+$ ion quenching of 1-4}

The fluorescence spectroscopic responses were reversible when the $\mathrm{Zn} 2+$ chelating reagentEDTANa2 (1.0 eqv.) It was added to $1-\mathrm{Zn}^{2+}$, $2-\mathrm{Zn}^{2+}, 3-\mathrm{Zn}^{2+}$ and $4-\mathrm{Zn}^{2+}$ solution, the fluorescence spectrum almost revived to the original shape of free $1-4$, which indicating the effective $\mathrm{Zn}^{2+}$ removal. The phenomenon proves that these compounds could serve as selectivity behaviour "on-off" sensor for $\mathrm{Zn}^{2+}$ (Fig. 8). 

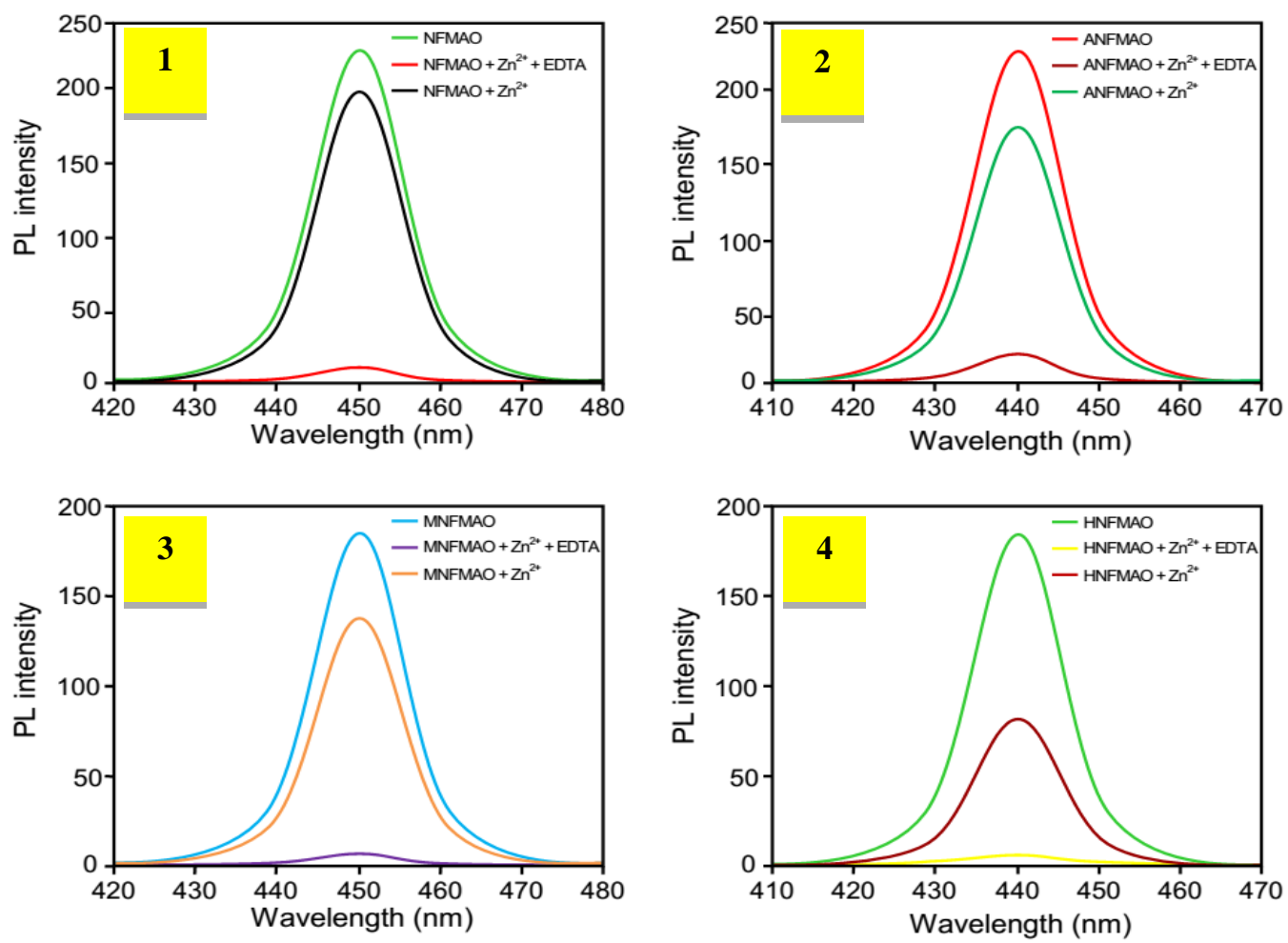

Fig. 8:Fluorescence Quenching Diagram of 1-4 by “On-Off” Sensor Method.

\subsection{Computational studies}

Density functional theory (DFT) has become an outstanding tool to predict a diverse effect of ground state properties of small and large molecules. Therefore, the ground-stategeometries of compounds 1-4 were optimized at B3LYP/6-31G $(\mathrm{d}, \mathrm{p})$ level theory using the Gaussian 03W program (Gonzalez et al. 2004). From the results, we understand structural and electronic properties of title compounds.

\subsection{Molecular electrostatic potential (MEP) analysis}

MEP has been mapped for all molecules as presented in Fig.S16 Higher negative and positive potential regions are shown in pink and green colours, respectively. The maximum negative regions are favourable for electrophilic attack, whereas maximum positive regions are attractive towards the nucleophilic attack. MEP represents the complete nuclear and electronic charge distribution of a molecule and is a very well-designed property to study the reactivity of the given molecule (Arockia doss etal.2015; Arockia doss et al. 2017).

The negative regions are indicated at around the oxygen and nitrogen atoms. As shown in Fig. S16, the negative and positive latent sites are around the electronegative (oxygen and nitrogen) atoms and the hydrogen atoms, respectively, while the remaining species are bounded by zero potentials. As we conclude from this, our title molecules are ready to involve both electrophilic and nucleophilic nature substitution reactions.

\subsection{HOMO-LUMO analysis}

The frontier molecular orbital's play a pivotal role in the electrical and optical properties, as well as in chemical reactions, UV-vis and fluorescence spectra (Padmaja et al. 2009; Tovar et al. 2008). The contour surfaces of the FMO (Frontier Molecular Orbital's) for molecule 2 are drawn in Fig.S17. In the compounds 1-4, the electron cloud distribution in HOMO and LUMO are spread over whole molecules. The difference in the range of charge separation between the HOMO and LUMO of those structures play a important role in the ICT. Furthermore, the difference on the values of $\Delta \mathrm{E}$ of compounds 1-4 was observed, when introduction of different electron donating character at phenyl core. As seen from Table 6, that the amino substitution in phenyl group does play a role on the orbital distribution (HOMO and LUMO) and also has a direct persuade on the electron density difference for the stabilizing ICT process. In this sense, it seems that the selection of a amino substitution has an advantageous effect among the designed candidate.As a result reveals, the decreasing trend of $\Delta \mathrm{E}$ gap of inspected compounds becomes $1>3>4>2$. We can monitor from Table 6 , the introduction of different substituent at phenyl core considerably change the $\Delta \mathrm{E}$ value.

Table 6: Calculated Energy Values (EV) of Compounds 1-4 in Gas Phase

\begin{tabular}{lllll}
\hline DFT/B3LYP/6-311G(d,p) & 1 & 2 & 3 & 4 \\
\hline E $_{\text {Hомо }}$ & -6.08 & -5.71 & -6.00 & -5.95 \\
E LUомо $_{\text {ELUмо-Hомо }}$ & -2.84 & -2.62 & -2.79 & -2.76 \\
Electrinegativity $(\chi)$ & 3.23 & 3.09 & 3.21 & 3.19 \\
Hardness $(\eta)$ & -4.46 & -4.16 & -4.39 & -4.35 \\
Electrophilicity index $(\psi)$ & 1.62 & 1.55 & 1.61 & 1.59 \\
Softness(s) & 6.16 & 5.61 & 6.01 & 5.94 \\
& 228.98 & 239.48 & 230.34 & 232.13 \\
\hline
\end{tabular}

Chemical hardness is indicated to the stability and reactivity of a chemical system, it measures the resistance to change in the electron distribution or charge transfer. In this intellect, chemical hardness corresponds to the gap between the HOMO and LUMO. The larger the HOMO-LUMO energy gap, the molecule becomes harder, more stable and less reactive the molecule. Table 6 contains the computed chemical hardness values for compounds 1-4. By analyzing the results, as show that compound 1 is harder and less reactive than the other compounds. The electronic chemical potential is used to study the electronegativity of a molecule. The increasing trend in electronic chemical potential for the compounds is $1<3<4<2$. The results of chemical hardness and electronic chemical potential of compounds 1-4 showed that compound 1 are harder and less reactive than compounds 2-4. Electrophilicity schedule measures the propensity or capacity of a species to accept electrons. To evaluate the principles of electrophilicity in compounds $1-4$, the electrophilicity value mention that compound 1 is a nucleophile better than the other compounds. Table 6 shows that compound 1 is strongest nucleophile whereas compound 2 is the strongest electrophile. 


\subsection{NLO analysis}

Organic materials with commutable OLED properties with NLO responses are sought for optoelectronic applications such as molecular-scale memory devices with multiple storage and nondestructive manner (Nakano et al. 2002; Geskin et al. 2003). A large variety of NLO switches exhibiting large changes in the hyperpolariza bility ( $\beta$ ), the molecular second-order NLO activity (Sajan et al. 2006; Kaatz et al. 1998). Some quantum chemical description which is dipole moment $(\mu)$, the polarizability $(\alpha)$, the anisotropy of the polarizability $(\Delta \alpha)$ and hyperpolarize bility $(\beta)$ have been used for describing the NLO properties in many computational studies (Savithiri et al. 2015). In this context, the design of NLO switches, that is, molecules computed for their hyperpolarize bility by alternate their substitution at the phenyl core. The quantum chemical descriptions calculated from the Gaussian output have been explained in earlier work. Ease in which NLO activity increase with increasing the polarizability, anisotropy of the polarizability and hyperpolarize bility.

A series of new molecules possesses a nonlinear optical property are designed, which includes $\mathrm{H}, \mathrm{NH}_{2}, \mathrm{CH}_{3}$ and $\mathrm{OH}$ positions of the phenyl center. According to Table 7, all values of each point out molecules are greater than urea. Therefore, NLO properties of our compounds are greater than urea. Results from Table 7, the general decreasing ranking of NLO properties should be as follows: $2>4>3>1$. With instant, molecule 2 is the best applicant for NLO properties.

Table 7:Non-Linear Optical Activity of Compounds 1-4

\begin{tabular}{|c|c|c|c|c|}
\hline NLO behavior & 1 & 2 & 3 & 4 \\
\hline Dipole moment $(\mu) \mathrm{D}$ & 6.48 & 9.44 & 7.18 & 6.92 \\
\hline Polarizability $(\alpha) \times 10^{-23} \mathrm{esu}$ & 1.45 & 1.47 & 1.55 & 1.54 \\
\hline $\begin{array}{l}\text { Anisotropy of the } \\
\text { Polarisability }(\Delta \alpha) \times 10^{-24} \mathrm{esu}\end{array}$ & 4.43 & 5.04 & 4.68 & 6.68 \\
\hline Hypolarizability $\left(\beta_{0}\right) \times 10^{-30} \mathrm{esu}$ & 1.80 & 3.74 & 2.20 & 2.27 \\
\hline
\end{tabular}

\section{Experimental}

\subsection{Materials and methods}

All reagents and chemicals were purchased from Aldrich chemicals Ltd and were used without further purification. The solvents were purified before use. Sensitivity study of probe compounds (1-4) towards different solvents, and metal ions determined out using chloride or nitrate salts of $\mathrm{Zn}^{2+}, \mathrm{Al}^{3+}, \mathrm{Pb}^{2+}, \mathrm{Ag}^{+}, \mathrm{Ni}^{2+}, \mathrm{Mn}^{2+}$, $\mathrm{Fe}^{2+}, \mathrm{Sr}^{2+}, \mathrm{Zr}^{2+}, \mathrm{Hg}^{2+}, \mathrm{Mg}^{2+}, \mathrm{Cd}^{2+}, \mathrm{Cu}^{2+}, \mathrm{Bi}^{3+}$ and $\mathrm{Sn}^{2+}$. All reactions were refluxed and monitored by TLC (Thin-layer chromatography). Melting points were determined on a melting point machine apparatus using open capillary. The FT-IR spectra (in $\mathrm{KBr}$ pellets) were recorded on a Rx-1 Perkin-Elmer spectrophotometer in the range $4000-400 \mathrm{~cm}^{-1}$. UV-Vis absorption spectra were recorded on a Shimadzu UV-2450 spectrophotometer by dissolving the sample in spectral grade ethanol and water using a $1 \mathrm{~cm}$ path-length quartz cell. A PerkinElmer LS55 fluorescence spectrometer was engaged to record the fluorescence (FL) spectra at room temperate. The option of excitation wavelengths was based on absorbance spectral characteristics. All the theoretical aspects were performed by using the Gaussian $03 \mathrm{~W}$ program package on a personal computer. Geometry optimization as approved out DFT method 6-31G (d, p) basis sets.

(Z)-N-((5-Nitrofuran-2-yl)methylene)anilineoxide(1)

Yield 77\%; m.p.: $82\left({ }^{\circ} \mathrm{C}\right)$; MF: $\mathrm{C}_{11} \mathrm{H}_{8} \mathrm{~N}_{2} \mathrm{O}_{4}$; Elemental analysis: Calcd (\%): C, 56.90; H, 3.47 N, 12.06; Found (\%):C, 54.91; H, 3.99; N, 12.01: IR (KBr, cm-1): 3051 (vAr-CH), 2922 (vali.-CH), $1540(v \mathrm{C}=\mathrm{N}), 1481(\mathrm{vC}=\mathrm{C}), 1015(\mathrm{vN}-\mathrm{O})$ (Fig.S1): ${ }^{1} \mathrm{H} \mathrm{NMR}(400$ $\left.\mathrm{MHz}, \mathrm{CDCl}_{3}, \delta,(\mathrm{ppm})\right): 7.49-8.05(\mathrm{Ar}-\mathrm{H}), 8.27$ (C-H) (Fig.S5); ${ }^{13} \mathrm{C}$ NMR (100 MHz, $\left.\mathrm{CDCl}_{3}, \delta, \mathrm{ppm}\right)$ : 111.2-155.9 (Ar-C); 171.3 (CH) (Fig.S9).
(E)-4-Amino-N-((5-nitrofuran-yl) methylene)anilineoxide(2)

Yield 72\%; m.p.: $66\left({ }^{\circ} \mathrm{C}\right)$; MF: $\mathrm{C}_{11} \mathrm{H}_{9} \mathrm{~N}_{3} \mathrm{O}_{4}$; Elemental analysis: Calcd (\%): C, 53.44; H, 3.67 N, 17.00; Found (\%):C, 52.01; H, 3.49; N, 16.71: IR (KBr, cm-1): 3046 (vAr-CH), 2923 (vali.-CH), $1539(v \mathrm{C}=\mathrm{N}), 1482(\mathrm{vC}=\mathrm{C}), 1017(\mathrm{vN}-\mathrm{O})$ (Fig.S2): ${ }^{1} \mathrm{H}$ NMR(400 $\left.\mathrm{MHz}, \mathrm{CDCl}_{3}, \delta,(\mathrm{ppm})\right)$ : 7.48-7.78(Ar-H), $8.20(\mathrm{C}-\mathrm{H}) ; 6.12(\mathrm{~N}-\mathrm{H})$ (Fig.S6); ${ }^{13} \mathrm{C}$ NMR (100 MHz, $\mathrm{CDCl}_{3}, \delta$, ppm): 112.7-150.7 (ArC); 173.1 (C-H) (Fig.S10).

(Z)-4-Methyl-N-(nitrofuran-2-ylmethylene)anilineoxide(3)

Yield $70 \%$; m.p.: $57\left({ }^{\circ} \mathrm{C}\right)$; MF: $\mathrm{C}_{12} \mathrm{H}_{10} \mathrm{~N}_{2} \mathrm{O}_{4}$; Elemental analysis: Calcd (\%): C, 58.54; H, 4.08; N, 11.38; Found (\%):C, 57.62; H, 3.88; N, 11.27: IR (KBr, cm-1): 3040 (vAr-CH), 2922 (vali.-CH), $1541(\mathrm{vC}=\mathrm{N}), 1480(\mathrm{vC}=\mathrm{C}), 1011(\mathrm{vN}-\mathrm{O})$ (Fig.S3): ${ }^{1} \mathrm{H}$ NMR(400 $\mathrm{MHz}, \mathrm{CDCl}_{3}, \delta$,(ppm)): 7.29-7.74 ( Ar-H), $8.46(\mathrm{C}-\mathrm{H}) ; 2.43(\mathrm{C}-$ H3) (Fig.S7); ${ }^{13} \mathrm{C}$ NMR (100 MHz, $\mathrm{CDCl}_{3}, \delta$, ppm): 113.4-145.7 (Ar-C); 172.5 (C-H) ; 29.73 (CH3) (Fig.S11).

(E)-4-Hydroxy-N-((5-nitrofuran-2-yl) methylene)anilineoxide (4)

Yield $75 \%$; m.p.: $72\left({ }^{\circ} \mathrm{C}\right)$; MF: $\mathrm{C}_{11} \mathrm{H}_{8} \mathrm{~N}_{2} \mathrm{O}_{5}$; Elemental analysis: Calcd (\%): C, 53.24; H, 3.27; N, 11.30; Found (\%):C, 52.27; H, 3.18; N, 10.67: IR (KBr, cm-1): 3042 (vAr-CH), 2921 (vali.-CH), $1543(\mathrm{vC}=\mathrm{N}), 1484(\mathrm{vC}=\mathrm{C}), 1013(\mathrm{vN}-\mathrm{O})$ (Fig.S4): ${ }^{1} \mathrm{H}$ NMR(400 $\left.\mathrm{MHz}, \mathrm{CDCl}_{3}, \delta,(\mathrm{ppm})\right)$ : 7.47-7.75(Ar-H), $7.98(\mathrm{C}-\mathrm{H}) ; 5.56(\mathrm{O}-\mathrm{H})$ (Fig.S8); ${ }^{13} \mathrm{C}$ NMR (100 MHz, $\mathrm{CDCl}_{3}, \delta$, ppm): 114.5-149.9 (ArC); 173.3 (C-H) (Fig.S12).

\section{Conclusions}

New aldosterones (1-4) have been synthesized, and its spectroscopic properties studied. The excited-state photophysical behaviour of compounds 1-4 has been deliberate by UV-visible and emission spectra. Additionally, the solvent power of the title compound and its solvatochromism behaviour can be quantitatively expressed byan LSE relationship using empirical Kamlet-Taft parameter scale. It has been depicted that the polarity in addition to the hydrogen bond donor or accepting ability of the solvent contributes to the stability of the excited-state. The chemo sensing actions of compounds 1-4 were also determined via fluorescence spectroscopy. The sensor showed an excellent selectivity with fluorescence quenching to $\mathrm{Zn}^{2+}$ over other cations in ethanolic solution. The chelating functionality proves that these compounds could to as a sensitive "on-off" sensor for $\mathrm{Zn}^{2+}$. The reactivity behaviour of title compounds were inferred by MEP analysis. The intended hyperpolarizability values show that compound 2 possesses good NLO properties.

\section{References}

[1] Butler O. T., Cook J. M., Harrington C. F., Hill S. J., Rieuwerts J., Miles D. L., 2008, Atomic spectrometry update. Environmental analysis, J. Anal. At. Spectrom, 23, 249. https://doi.org/10.1039/b718954k.

[2] Yanagida T., Ishii Y., 2009, Single Molecule Dynamics in Life Science; Wiley-VCH: Weinheim, Germany. 328 , https://doi.org/10.1002/cbic.200900416.

[3] Szmacinski H., Gryczynski I., Lakowicz R., 1993, Calciumdependent fluorescence lifetimes of indo-1 for one- and two-photon excitation of fluorescence, J. Photochem. Photobiol, 58, 341-345. https://doi.org/10.1111/j.1751-1097.1993.tb09571.x.

[4] Lakowicz J. R., 1983, Principles of Fluorescence Spectroscopy; Plenum Press: New York.https://doi.org/10.1007/978-1-4615-76587.

[5] Czarnik A. W., 1994, Fluorescent Chemosensors for Ion and Molecule Recognition; Instrumantation Science \& Technology, Taylor \& Francis, UK, 22, 405-406.

[6] Lakowicz J. R., 1995, Fluorescence spectroscopy of biomolecules. In Encyclopedia of molecular biology and molecular medicine; Meyers, R. A., Ed.; VCH Publishers: New York. 
[7] Dudev T., 2003, Principles governing Mg, Ca, and $\mathrm{Zn}$ binding and selectivity in proteins, Chem. Rev., 103 (3), 773-788. https://doi.org/10.1021/cr020467n.

[8] Laity J. H., Lee B. M., Wright P. E., 2001, Zinc finger proteins: new insights into structural and functional diversity,Curr. Opin. Struct. Biol., 11 (1), 39-46. https://doi.org/10.1016/S0959440X(00)00167-6.

[9] Datta B. K., Mukherjee S., Kar C., Ramesh A., Das G., 2013, Zn ${ }^{2+}$ and pyrophosphate sensing: selective setection in physiological conditions and application in DNA-based estimation of bacterial cell numbers, Anal. Chem., 85 (17), 8369-8375. https://doi.org/10.1021/ac401871t.

[10] Berg J. M., Shi Y. G., 1996, the galvanization of biology: a growing appreciation of the roles of zinc, Science 271 (5259), 10811085. https://doi.org/10.1126/science.271.5252.1081.

[11] Vallee B. L., Falchuk K. H., 1993, The biochemical basis of zinc physiology, Physiol. Rev., 73(1), 79-118. https://doi.org/10.1152/physrev.1993.73.1.79.

[12] Scrimgeour A.G, Stahl C. H., McClung J. P., Marchitelli L. J.,Young A. J., 2007, Moderate zinkseficiencynegativety affects biomechanical properties of rat tibiae indepently of body composition, J. Nutr. Biol., $18(12), \quad 813-9$. https://doi.org/10.1016/j.jnutbio.2006.12.018.

[13] (a) Bush A. I., 2000, Metals and neuroscience, Curr. Opin. Chem Biol., 4(2), 184-191. https://doi.org/10.1016/s1367-5931(99)000733.(b) Frederickson C. J., Burdette S. C., Frederickson C. J., Sensi S. L., Weiss J. H., Yin H. Z., Balaji R. V., Truong-Tran A. Q., Bedell E., Prough D. S., Lippard S. J., 2004, Method for identifying neuronal cells suffering zinc toxicity by use or a novel fluorescent sensor,J. Neurosci. $\quad$ Methods, 139(1), 79-89. https://doi.org/10.1016/j.jneumeth.2004.04.033

[14] Frederickson C. J., Koh J. Y.,Bush A. I., 2005, The neurobiology of zinc in heaith and disease, Nat. Rev. Neurosci., 6(6), 449-469. https://doi.org/10.1038/nrn1671.

[15] Bush A. I., Pettingell W. H., Multhaup G., Paradis M., Vonsattel J. P., Gusella J. F., Beyreuther K., Masters C. L., Tanzi R. E., 1994, Rapid induction of alzheimer a beta amyloid formation by zinc, Science., 265(5177), 1464-1470. https://doi.org/10.1126/science.8073293.

[16] Silva A. P. De., NimalGunaratne H. Q., Gunnlaugsson T., Huxley A. J. M., McCoy C. P., Rademacher J. T., Rice T. E., 1997, Signaling recognition events with fluorescent scensor and switches, Chem.Rev., 97(5), 1515-1566. https://doi.org/10.1021/cr960386p.

[17] Carol P., Sreejith S., Ajayaghosh A., 2007, Ratiometric and NearInfrared molecular probes for the detection and imaging of zinc ions, Chem. Asian J., 2(3), 338-348. https://doi.org/10.1002/chin.200722277.

[18] Kimura E., Aoki S., 2001, Chemistry of zinc (II) fluorophore sensors, BioMetals, 14(3-4), 191-204. https://doi.org/10.1023/A:1012942511574.

[19] Jiang P., Guo Z., 2004, Fluorescent setection of zinc in biological systems: recent development on the design of chemosensors and bioscensors, Coord.Chem. Rev., 248(1-5), 205-229. https://doi.org/10.1016/j.cct.2003.10.013.

[20] Que E. L., Domaille D. W., Chang C. J., 2008, Metals in neurobiology: probing their chemistry and biology with molecular imaging, Chem. Rev., 108(5), 1517-1549. https://doi.org/10.1021/cr078203u.

[21] Hamer J., Macaluso A., 1964, Nitrones, Chem. Rev. 64(4), 473 495. https://doi.org/10.1021/cr60230a006.

[22] Tufariello J., 1979, Alkaloids from nitrones, J. Acc. Chem. Res., 12(11), 396-403. https://doi.org/10.1021/ar50143a003.

[23] Black D. St. C., Crozier R. F., Davis V. C., 1975, Organic Synthesis., 8, 205-221.

[24] Huisgen R., 1963, 1,3-Dipolar cycloadditions. Past and future, Angew. Chem. Int. Ed., 2, 565-598. https://doi.org/10.1002/anie.196305651.

[25] Hassan A., Wazeer M. I. M., Saeed M.T., Siddiqui M. N., Asrof S K., 2000, journal of physical organic chemistry., 13(8), 443-451.

[26] Turfariello J.J., 1984, 1,3-Dipolar cycloaddition chemistry, S. Padwa(Ed) Wiley, NewYark, pp.83-168.

[27] Turfariello J.J., 1979, Alkaloids from nitrones, Accchem Res., 12(11), 396-403. https://doi.org/10.1021/ar50143a003.

[28] Kikuchi K., 2010, Design, synthesis and biological application of chemical probes for bio-imaging, Chem. Soc. Rev., 39(6), 20482053. https://doi.org/10.1039/b819316a.

[29] Xu Z., Yoon J., Spring D. R., 2010, Fluorescent chemosensors for $\mathrm{Zn}^{(2+)}$,Chem. Soc. Rev., 39(6), 1996-2006. https://doi.org/10.1039/b916287a.

[30] Quang D. T., Kim J. S., 2010, Fluoro- and chromogenic chemodosimeters for heavy metal ion detection in solution and biospeci- mens, Chem Rev https://doi.org/10.1021/cr100154p.

[31] Wu J., Liu W., Ge J., Zhang H., Wang P., 2011, New sensing mechanisms for design of fluorescent chemosensors emerging in recent years, Chem. Soc. Rev., 40, 3483-3495. https://doi.org/10.1039/c0cs00224k.

[32] Kamlet M. J.Taft R.W., 1976, thesolvatochromic comparison method. I. The .beta.-scale of solvent hydrogen-bond acceptor (HBA) basicities, J. Am. Chem. Soc., 98(2), 377-383. https://doi.org/10.1021/ja00418a009.

[33] Reichardt C., 2006, Solvents and Solvent Effects in Organic Chemistry, wiley-vch, $3^{\text {rd }}, 653$.

[34] Kawski A., Kuklinski B., Bojarski p., 2006, Excited state dipole moments of N,N-dimethylaniline from thermochromic effect on electronic absorption and fluorescence spectra, Chemical physics., $320 \quad(2-3), \quad 188-192$ https://doi.org/10.1016/j.chemphys.2005.07.007.

[35] Ghazy R., Azim S.A., Shaheen M., El-Mekawey F., 2004, Experimental studies on the determination of the dipolemoment of some different layer dyes, Spectrochim.Acta A., 60, 187.

[36] (a) Kawski A., 2002, on the estimation of excited-state dipole moments from solvatochromic shifts of absorption and fluorescence spectra, Journal of Physical Sciences.,57, 255-262.

[37] (a) Lippert E., Electrochem Z.,1957, Ber. Bunsenges. Phys. Chem., 61, 962. (b) Lippert E., Naturforsch Z., 1955, Dipolmoment und elektronenstruktur von angergtenmolekulen,Eingegangen am 11.10a 541-545. https://doi.org/10.1515/zna-1955-0707.

[38] Husain M. M., Sindhu R., Tandon H.C., 2012, Photophysical properties and estimation of ground and excited state dipole moments of 7-diethylamino and 7-diethylamino-4-methyl comarin dyes from absorption and emission spectra, Eur. J. Chem., 3, 87-93. https://doi.org/10.5155/eurjchem.3.1.87-93.519.

[39] Gonzalez C., Pole J. A., Frisch M. J., Trucks G.W., Schlegel H. B., Scuseria G. E., Robb M. A., Cheeseman J. R., Montgomery Jr J. A., Vreven T., Kudin K. N., Burant J. C., Millam J. M., Iyengar S. S., Tomasi J., Barone V., Mennucci B., Cossi M., Scalmani G., Rega N., Peters G.A., 2004, Gaussian Inc, Wallingford, CT.

[40] (a) Arockia doss M., Savithiri S., Rajarajan G., Thanikachalam V., Saleem H., 2015, Synthesis, spectroscopic (FT-IR, FT-Raman, UV and NMR) and computational studies on 3t-pentyl-2r,6cdiphenylpiperidin-4-one semicarbazone, SpectrochimicaActa Part. A., 148, 189-202. https://doi.org/10.1016/j.saa.2015.03.117. (b) Arockia doss M., Rajarajan G., Thanikachalam V., Selvanayagam S., Sridhar B., 2017, Synthesis, spectroscopic(UV-Vis, FT-IR and NMR), single crystal XRD of 3,5-diethyl-2,6-di(thiophen-2 yl)piperidine-4-on-1-ium picrate: A comprehensive experimental and compoutational study, J. Mol. Struct., 1128, 268-278. https://doi.org/10.1016/j.saa.2015.03.117.

[41] (a) Padmaja L., Ravikumar C., Sajan D., Hubert Joe I., Jayakumar V. S., Pettit G. R.,Nielsen O. F., 2009, Density functional study on the structural conformations and intramolecular change transfer from the vibarational spectra of the anticancer drug combretastation-A2, J. Raman Spectrosc., 40, 419 https://doi.org/10.1002/jrs.2145. (b) Tovar R. M., Johnson K. P., Ashline K., Seminario J. M., 2008, Effects of substituents on molecular devices, Int. J. Quantum Chem., 108, 1546-1554. https://doi.org/10.1002/jrs.2145.

[42] (a) Nakano M., Fujita H., Takahata M., Yamaguchi K., 2002, Theoretical study on second hyperpolarizabilities of phenylacetylene dendrimer: toward an understanding of structure-property relation in NLO responses of fractal antenna dendrimers,J. Am. Chem. Soc., 124 (32), 9648-9655. https://doi.org/10.1021/ja0115969. (b)Geskin V. M., Lambert C.,Bredas J. L., 2003, Origin of high second-and thirdorder nonlinear optical response in ammonio/borate diphenylpolyene zwitterions: the remarkable role of polarizad aromatic groups,J. Am. $\begin{array}{llll}\text { Chem. } & \text { Soc., } & 125 & \text { (50), }\end{array}$ 15658.https://doi.org/10.1021/ja035862p.

[43] Sajan D., Hubert Joe I., Jayakumar V. S., Zaleski J., 2006, Structural and electronic contributions to hyperpolarizability in methyl p-hydroxy benzoate, J. Mol. $\quad$ Struct., 485 , 43-53. https://doi.org/10.1016/j.molstruc.2005.09.041.(b) Kaatz P., Donley E. A., Shelton D. P., 1998, A comparison of molecular hyperpolarizabilities from gas and lisuis phase measurements, J. Chem. Phys., 108, 849. https://doi.org/10.1016/j.molstruc.2005.09.041.

[44] Savithiri S., Arockia doss M., Rajarajan G., Thanikachalam V., Bharanidharan S., Saleem H., 2015, Spectroscopic (FT-IR, FT-Raman) and quantum mechanical studies of 3t-pentyl-2r,6c-diphenylpiperidine-4-one thiosemicarbazone, Spectrochim. Acta Part A., 136 782.https://doi.org/10.1016/j.saa.2014.09.095. 